\title{
Taking Stock of a Genre-Based Pedagogy: Sustaining the Development of EFL Students' Knowledge of the Elements in Argumentation and Writing Improvement
}

\author{
Tingting Zhang and Lawrence Jun Zhang *(i) \\ Faculty of Education \& Social Work, The University of Auckland, Auckland 1023, New Zealand; \\ christine09cool@163.com \\ * Correspondence: lj.zhang@auckland.ac.nz; Tel.: +64-96-238-899 (ext. 48750)
}

check for

updates

Citation: Zhang, T.; Zhang, L.J.

Taking Stock of a Genre-Based

Pedagogy: Sustaining the

Development of EFL Students'

Knowledge of the Elements in

Argumentation and Writing

Improvement. Sustainability 2021, 13,

11616. https://doi.org/10.3390/

su132111616

Academic Editor: Jordi Colomer Feliu

Received: 17 September 2021

Accepted: 18 October 2021

Published: 21 October 2021

Publisher's Note: MDPI stays neutral with regard to jurisdictional claims in published maps and institutional affiliations.

Copyright: (c) 2021 by the authors. Licensee MDPI, Basel, Switzerland. This article is an open access article distributed under the terms and conditions of the Creative Commons Attribution (CC BY) license (https:// creativecommons.org/licenses/by/ $4.0 /)$.

\begin{abstract}
The capacity to make effective argumentation in English writing is considered as a crucial ability in the field of second language writing. Currently, Chinese teachers of English as a foreign language (EFL) adopt the product approach to teach argumentative writing, in which they stress the mode of learners' written production and show little concern with cognition. For students' sustainable development in argumentation skills, teachers are encouraged to employ a genre-based approach to cultivate students' knowledge about different elements in argumentation. However, few empirical studies have investigated the efficacy of such classroom-based instruction on learners' comprehensive development in EFL writing, including their knowledge about writing and performance in producing argumentation. This is particularly the case with reference to Chinese students learning to write argumentative texts in EFL. To fill the research gap, this quasi-experimental study was conducted with 74 EFL sophomores, who were randomly allocated to either an experimental group or a comparison group. The experimental group received a genre-based writing approach, while the comparison group experienced their conventional writing instruction. Students' changes were analysed using pre- and post-writing test measures, open-ended questionnaires, and stimulated recall interviews. Our findings revealed more changes in the experimental groups' knowledge about argumentation following the genre-based writing treatment than the comparison group. Specifically, the experimental group's progress was obvious in the way they displayed their knowledge of the structure of discourse moves and of language features specific to the argumentative genre. They began to express their knowledge of the content, process, intended purposes, and audience awareness towards producing more genre appropriate texts in argumentation. They also showed enhanced selfreflection on their knowledge of argumentation. In addition, the genre-based approach had a positive effect on the experimental group's argumentative writing development, as evidenced in their use of discourse move structures and their overall writing quality improvement. The conventional writing approach was not as effective in helping students to write an argumentation. Writing proficiency effects were observed in terms of the extent to which the students were developed. Pedagogical implications and limitations are also discussed.
\end{abstract}

Keywords: genre-based writing pedagogy; argumentative writing; genre knowledge; writing performance

\section{Introduction}

Writing is a significant skill that all students need to develop in order to enhance effective communication. However, it is also a difficult skill to acquire [1-6]. The degree of difficulty exacerbates when students have to learn to write in a second language, as is the case in English as a foreign language [7-9]. It is even more so when they have to learn to write an argumentative text that requires high levels of critical thinking and logical reasoning $[9,10]$. Argumentation is defined as a rhetoric process from the use of structural logic in giving opinions, supporting facts, and counteractive actions with appropriate tone, voice, and language to convince readers about a controversial issue in such contexts [11,12]. 
Indeed, we rely heavily on argumentative writing to assess EFL students' writing ability in various well-known standardized tests, such as the College Entrance Examination (CEE), the College English Test (CET), the International English Language Testing System (IELTS), and the Test of English as a Foreign Language (TOEFL) [13]. Simultaneously, students also need to extend their argumentative knowledge to develop their critical literacy and stance expression in the academic field in the tertiary level $[4,9,14,15]$. Taking an effective argumentation is thus considered as an important skill for student writers for achieving exam success and sustainable academic achievements. However, the existing literature has revealed that L2 students were not proficient in argumentative writing $[4,10,16]$. Particularly, L2 students' argumentative writing is regularly found with single-voiced structure, personal stories, or without counteractive views [17-19]. This status is considered as student writers' insufficiency in and lack of flexible rhetorical ability and audience awareness of a situation in which the text is generated [20].

More L2 writing scholars noticed difficulties in the teaching of argumentation in the academic contexts [13,21-23]. As Kibler [22] argued, L2 students had language and culturalrelated rhetorical challenges of argumentation in academic writing. However, L2 writing teachers who focused on linguistic accuracy rather than content and context resulted in students' lack of awareness and competence in argumentation with different communities [5]. In this situation, some specialists advocated for the genre-based instruction in the writing classroom to develop students' sustainable ability in argumentation [16,20]. However, few intervention studies have been conducted to evaluate its efficacy. To fill this research gap, this study was carried out to investigate the effects of genre-based writing instruction with a comprehensive perspective on EFL students' development in their knowledge of different elements in argumentation and improvement in argumentative writing.

\section{Literature Review}

\subsection{Conceptualisation of Argumentation in Genre Studies}

Genre notions and theories are widely used to address writing matters, in which writing can be defined as a staged, goal-oriented text-generation and social process with a definite communicative purpose within a specific community $[24,25]$. It has a potential to improve the exploration of argumentation in second or foreign language writing. We, therefore, use the term "argumentative genre" to refer to a form of thinking process where writers present a personal viewpoint and related support with putative readers on a topic or issue in such a genre (e.g., a research article written for a teacher in a professional course, a five-paragraph essay written for the English teacher in the pedagogical genre).

Framed in a genre, writers construct their argumentation with an acceptable logical structure, propriate visual language, and proper reasons that an audience in a community would find persuasive [26]. For example, writers in the social sciences and sciences generally emphasise their proposition using structural moves about arguments, counterarguments, and rebuttals [19]. The students' stronger rebuttal evidence, more balanced reasoning in argument and counterargument in the acknowledgment of different perspectives, and alignment of the reader and the writer's position could predict their high quality of argumentative writing [18]. For the choice of language, the argument is achieved through different language markers the writer adopts in expressing claims and evidence. Examples include showing the writers' intense claims with "I strongly propose the idea that this is where we should pay the significant attention"; constructing counter-claim markers such as "it cannot be denied that ... "; and showing support for the data with "this sector is the most important because, this is primarily because" [27] (pp. 70-73). For the choice of proper reasons, a well-constructed semantic network of linguistic structures and conventions and the ability to manipulate such resources (e.g., syntactic operation by acknowledging sources, quoting from sources, and explaining the quotes) significantly constitute the argumentation in academic contexts [26].

These findings indicate that proficient argumentative writers own a range of resources that enable them to construct argumentation in different communities. A genre knowledge 
framework might help to reveal writers' acquired knowledge or resources of argumentation. Specifically, genre knowledge is defined as students' conceptual knowledge, such as the ability to recognise features in a specific genre [28], and the ability to analyse the context and purpose of the genre before making selections in their writing [25,29-31]. Tardy [32] developed a genre knowledge model to identify the patterns of learners' knowledge of specific genres during writing. In this model, four elements of genre knowledge, namely formal knowledge, rhetorical knowledge, process knowledge, and subject-matter knowledge, are presented. Tardy suggests that these four elements are distinct and interact with one another. Formal knowledge addresses students' understanding of textual features in a specific genre, such as conventional structural steps, lexicon-grammatical tradition, and textual forma. Rhetorical knowledge refers to students' understanding of a genre's evident purpose in a local context, a sophisticated awareness of audiences' beliefs, and the awareness of situated variables in different social contexts. Process knowledge refers to all the composing processes in achieving the planned rhetorical action in a writing task. Subject-matter knowledge pursues the content in a domain, such as background knowledge and content of the subject matter in completing a writing task. It is important to note here that novice writers and expert writers differ in the amount of genre knowledge they have. Specifically, novice L2 writers' dimensions of genre knowledge showed limited overlap, and they had better formal knowledge than other elements [31,33]. In the L2 writing context, some scholars have explored the development of students' knowledge in various genres, such as the summary genre [34], the literature review genre [35], and the research paper genre [36]. Uzun [37,38] recommends that there is a need for a comprehensive exploration of students' argumentation within the genre framework. Thus, the organisation of students' genre knowledge about different elements in argumentation warrants further investigation.

\subsection{Sociocultural Theory and Genre-Based Instruction}

Sociocultural theory, which is widely used to explore human learning and development, was founded by notable educator Lev Vygotsky. From his perspective, human development is a dialectic process of being engaged in the centre of learning communities after participating in social interactions [39]. It emphasises the close reciprocity in which the Zone of Proximal Development (ZPD), mediation, and internalisation operate as interacting with each other. These are sociocultural views that people learn and develop (ZPD) through others' mediation and individual internalisation [40]. A number of L2 English writing scholars (for example, [41,42]) support Vygotsky's view of human development, and they have also confirmed the efficiency of social constructivist activities (mediation), as it acts as a bridge between learners' writing improvement (ZPD) and personal situation, such as personal background, social context, and cognition (internalisation).

Genre-based instruction has been well investigated in L1 and ESL writing contexts, where students are provided with accessible mediation so that they may establish a basic understanding of discourse features in such a genre [43]. Having acknowledged the important role of genre, a group of scholars have focused on applying genre-based activities to the writing instruction with productive outcomes [16,31,44]. Generally, three main schools in the genre field - the Australian Systemic Functional Linguistics (SFL), the New Rhetoric (NR), and English for Specific Purposes (ESP)—have developed, each with different teaching focuses and with targeted learners. Both ESP and SFL genre-based approaches have dominated the L2 writing instructional field as they allow explicit teaching; moreover, these explicit tasks are encouraged to be used to provoke learners' cognition and writing improvement. The content of genre-based approaches (SFL, ESP) and students' development within these two approaches will be reviewed next.

\subsection{Genre-Based Instruction of Argumentation}

The existing literature on argumentation revealed that $\mathrm{L} 2$ writers had limited strategies in making the viewpoint and establishing their support. For example, L2 student 
writers' argumentative written texts often contain noticeable subjective views, few counterargument features, and overloaded personal or vague reasons, detached from critical thinking and evaluation about such a topic [17]. The L2 students' limited strategies strongly influence their writing performance in the test and future scholarship. This burning issue needs to be addressed, as there is a demand for university L2 students to construct their writing with clear, coherent, and well-organised argument in the academic context [9]. Some specialists have speculated that an effective argumentation cannot be taken for granted, and the genre-based practices may provide opportunities to develop L2 writers' knowledge and writing outcomes in argumentation [16,20]. In light of genre theories, genre-based practices provide students with knowledge about structural moves, linguistic forms, rhetoric awareness, and accessible contexts so that the intervention may aid students in making the transition to the generic literacies in argumentation expected at the university [9,43]. According to Feez and Joyces' [45] Teaching/Learning Cycle (TLC) within SFL genre theory, students are scaffolded for noticing target language use (mode), interactions (tenor), and different places (field) in a genre with the following three stages: (1) deconstruction; (2) joint text construction; and (3) independent construction of the text. A group of studies has shown that the genre-based TLC could facilitate L2 students' knowledge learning and language use in their writing [16,31,46,47]. Some genre experts in ESP claimed that students should be taught by conducting text analysis of rhetorical move structures, lexicogrammatical patterns, communicative aims, and variations across situations $[24,48]$. That is, the ESP-based genre method involves both the elaboration of schemata for the argument organisation and the maintenance of conversational interaction between the reader and the intended audience, which may help students engage with the genre community [49]. Some empirical studies have reported the positive effects on students' formal knowledge [50], rhetorical awareness [16,51], and writing structures [52] after the genre analysis.

The contribution of genre-based instruction to students' learning of argumentative writing has been investigated in several studies focusing on different aspects [26,53-55]. Pessoa [26], for example, administered a series of genre-based workshops to teach history undergraduate students how to use argumentation in a world history course in an American university in the Middle East. The study proposed that the instructors' explicit directions concerning the ways of making a claim, acknowledging sources, and quoting from sources were useful to foster learners' sufficient genre awareness in historical argumentation, which, in turn, contributed to their positive writing outcomes. Devitt, Reiff, and Bawshi [53] explored how an explicit genre-based approach shaped students' genre awareness and facilitated their development of writing in argumentation. They also suggested that if the learners were taught how to read, analyse, and write argumentative assignments in various situations while considering the audience and the author's aim, it might enable them to respond to argumentative tasks more effectively. Vander Heidi's [54] intervention study with 20 high school students in the United Sates explored a possible correlation between the genre-based approach and their writing performance in argumentation. They reported that the genre-based intervention facilitated students' discourse moves and rhetoric awareness in argumentation. Gill and Janjua [55] investigated the development of $40 \mathrm{EFL}$ undergraduates' writing coherence (e.g., organisation, lexical, and grammatical features) in argumentation in Pakistan. They showed that their genre-based writing teaching facilitated students' organisation in argumentative writing.

These are interesting and encouraging findings. Unfortunately, these studies did not include a comparison group in research design, which may challenge the claims made of the effectiveness of the genre-based instruction. Moreover, it is important to examine if the genre-based practices have an effect on both EFL students' knowledge as well as writing improvement in argumentation, which could provide further insights into the role of genre-based pedagogy. This study, thus, aims to address this research gap with the following two research questions: 
(1) Does genre-based writing instruction have any impact on Chinese EFL students' genre knowledge? If yes, how do their argumentative knowledge and reflections about their knowledge change over time?

(2) Does genre-based writing instruction have any impact on Chinese EFL students' writing improvement? If yes, how does their argumentative writing performance change over time?

\section{Method}

\subsection{Participants}

Convenience sampling was used in the recruitment of participants for easy approachability. With the official approval from the University of Auckland Ethics Committee on Human Participants, 74 sophomore students who came from non-English major backgrounds, including Materials Science, Physics, Chemistry, Geology, Statistics, and Business, from a medium-ranking university in China, were invited to participate in the study on a voluntary basis. They had learned English for about eight years prior to this research. To ascertain that participants' writing proficiency across experimental and comparison groups was similar, all participants were divided into higher and lower writing proficiency levels based on their writing scores (the accuracy of grammar and lexis, the vocabulary range, language usability, textual coherence, and argumentative ability) in the pre-test of this research. Then, participants of each higher- or lower-level were assigned randomly to the experimental group or the comparison group. Finally, each group comprised 37 students. In addition, eight participants ( $n=4$ in experimental group; $n=4$ in comparison group) were selected on the basis of convenience sampling [56] to attend the interviews. Descriptive statistics showed that the two groups had similar backgrounds in their experience of English writing, years of English learning, and their average age.

\subsection{Writing Instruction}

This research took place in 2019 as part of a two-semester sequence of optional English courses, including academic English writing, reading, listening, and speaking. They were designed to familiarise the undergraduates in using academic English for the tertiary level education. In particular, the academic writing course sought to foster students' written expression toward a more objective direction for the placement and development of a claim in the academic context. During the study, all the participants were enrolled in an eight-week writing course. The instruction was provided once a week for $45 \mathrm{~min}$. The experimental group was taught using the genre-based pedagogy, while the conventional method was used for the comparison group. The course teachers for both groups had similar academic and teaching experiences.

\subsubsection{Genre-Based Writing Intervention}

The genre-based writing instruction was designed mainly based on TLC and genre knowledge theory in consideration of the EFL writing context. Table 1 is an overview of the intervention conducted with the experimental group. The six stages of the genrebased writing instruction were implemented. On the one side, students were taught to notice the different elements of argumentative knowledge in the pedagogical genre (i.e., as typically used in 5-paragraph essays and research articles), drawing on Tardy's [32] genre knowledge model. On the other side, students were guided with the TCL scaffolding system for constructing individual knowledge and written texts with the teachers' help [45]. In this vein, the genre-based approach engaged participants in learning how to analyse texts with generic awareness, organise their individual knowledge framework, and compose their writing with acquired genre knowledge. 
Table 1. Instructional Stages.

Stage 1: Argumentative Knowledge Activation (Week 1)

A: Teacher activates students' previous knowledge in argumentation.

B: Students reflect on their mastery of knowledge and written expression in argumentation.

Stage 2: Teacher-led Genre-based Deconstruction (Week 2-3)

A: Teacher introduces the concept and content of knowledge about different elements, including formal, rhetorical, process, and subject levels in argumentation.

B: Teacher guides students to deconstruct authentic academic texts with knowledge about different elements and written expressions in argumentation.

Stage 3: Students' Deconstruction (Week 4-5)

A: Teacher guides students to analyse their individually collected articles using a genre knowledge framework.

B: Teacher asks questions, organises group discussions, and prepares prompts with charts for students to follow.

Stage 4: Scaffolding knowledge Framework Construction (Week 6)
A: Teacher organises classroom activities to help students' knowledge building (e.g., structural types, language types, content types,
arguing with audience, arguing with a purpose).
B: Students construct personal knowledge framework in argumentation.

Stage 5: Scaffolding joint Text Construction (Week 7)

A: Teacher organises activity to construct an argumentative written text with students.

B: Students construct argumentative written texts in groups with teachers' support.

Stage 6: Independent Practice (Week 8)

A: Teacher organises independent writing practice and gives formative feedback to help students use argumentative knowledge in their writing.

B: Students independently use argumentative knowledge in writing and become active with self-reflection in the process.

In the comparison group, the teacher focused on teaching writing with the following two foci: content and mode. The writing course was conducted with the aim of producing a logical written text in argumentation, akin to what was designed as the end production in the experimental group. Specifically, the teacher helped students to understand the language features and content in each sentence of the text. The teacher also guided students to develop some templates in paragraphs and essays to help them imitate model articles in argumentative writing. However, the writing teacher did not explicitly scaffold her teaching using the genre-based approach.

\subsubsection{Training the Intervention Teacher}

The training enables the instructor to develop the central role in preparing curriculum materials and activities for writing classes and, in turn, support students' genre engagement in the classroom [43,57]. Therefore, the teacher in the experimental group was invited to attend a four-week (three hours per week) teacher training before the intervention. In these workshops, the basic genre theories and genre approaches in L2 writing were presented, followed with an explication of the nature of argumentative writing with the provision of the curriculum package of the genre-based writing course. The training workshops concluded with discussions of the challenges, proposed solutions, and possibilities of adjusted instructional procedures. After the teacher training, the teacher was allocated to an experimental group to implement an eight-week genre-based writing instruction.

\subsection{Instruments for Data Collection}

\subsubsection{Pre- and Post-Instructional Questionnaires}

To inquire about the changes in the Chinese students' knowledge in argumentation, pre- and post-instructional genre knowledge questionnaires were conducted. Each questionnaire was administrated after the pre- and post-writing test. All participants were invited to answer 8 open-ended questions (Appendix A). These questions were designed to collect students' argumentative knowledge, including formal elements (macro-structure, micro-linguistic, content); process elements (psychological process); and rhetorical elements (writers' understanding of their position, the purposes of argumentation, communicative 
purposes, audience characteristics). These questions aimed to identify the knowledge and conceptualisations of argumentation the participants had developed before instruction in the EFL writing context. Eight weeks later, when the intervention was completed, the same questions were asked of the participants in the post-instructional questionnaire to identify if or how their initial argumentative knowledge had changed over time. For the questionnaire construction, a series of established studies about students' genre knowledge exploration in L2 writing was consulted $[4,31,32,36,58]$. The questionnaires were built in English and translated into Chinese so that the participants could easily understand them. This process included the researcher's translation from English to a Chinese version and lecturer's back-translation from Chinese to English. The differences between these English and Chinese versions were discussed to ensure the quality of the Chinese version. The Chinese version of the questionnaire was piloted to check the validity and readability.

\subsubsection{Pre- and Post-Instructional Interviews}

To expand the information obtained from the questionnaires about students' knowledge of argumentation, we invited eight students to participate in our follow-up interviews (four in the experimental group, four in the comparison group). During the interviews, we gave each participant their answers in the questionnaires and texts that they had written before and after the instruction and asked them whether and how their knowledge of argumentation had changed and why, and how the writing course helped them to develop their genre knowledge and writing ability in argumentation. Appendix B presents these interview questions. These participants responded to the interview questions in Mandarin Chinese, their first language. All interviews were recorded with participants' written consent and permission. The transcripts were checked by the students and translated into English by the first author and checked by the second author, both of whom are fluent speakers and writers in Mandarin Chinese.

\subsubsection{Pre- and Post-Instructional Writing Tests}

Argumentative essays with given topics and prompts, which were designed as a real discussion (Appendix C), were used to explore students' writing improvement, hoping to draw out students' actual argumentative writing ability. In our research, both the experimental and comparison groups were invited to complete two writing tasks at the beginning and the end of writing instructions. During each writing test, all participants were invited to write at least 250 words for the argumentative writing test within a 65-min timeframe in classroom settings. They were not allowed to search for information from books or the internet. For the selection of the writing topic, five experienced English teachers from the university and 15 nonparticipant undergraduates were invited to ascertain the moderate difficulty level for argumentation. Finally, the topic of "education" was selected. To supervise the effects caused by the different difficulty of writing tasks, we took a counterbalance design to deal with the two writing tests. That is, two similar writing prompts about "education" were designed. In the pre-test, half of the participants wrote their essays with prompt $\mathrm{A}$, and the rest of them wrote on the essays with prompt B. In the post-test, students who had written the essay with prompt A before the intervention wrote essays with prompt B.

\subsection{Procedures for Data Collection}

At the beginning of this research, participants were invited to complete an argumentative writing test, questionnaire, as well as a stimulated recall interview for us to collect baseline data from both groups. Upon completion of the eight-week writing course, a postwriting test, questionnaire, and recall interviews were conducted. Both the experimental and the comparison groups were provided with the instruction in argumentation. In order to guarantee the comparability of the two groups, we ensured that both groups had the same writing assignments during and after the writing course. 


\subsection{Data Coding and Analysis}

In line with genre theories and specifically Tardy's genre knowledge model [32], students' knowledge changes in argumentation were analysed on the basis of the data collected from the pre- and post-instructional questionnaires and interviews. The questionnaires were analysed through content analysis (CA) [56] and presented with code numbers and code content. That is, the findings were presented as the numbers of codes and a detailed description of the meaning about the codes [59]. Doing so was supposed to help us have a better understanding of changes in students' knowledge not only as a group trend but also with specific reference to the substance in their argumentation.

We adopted a concept-driven and data-driven approach to construct the coding system [60]. That is, the categories in the coding system were formulated by the employment of the genre knowledge model and participants' responses. Two coders were invited to discuss the codes, categories, and subcategories of the coding system to increase the reliability and the credibility. The intra-coder agreement was $88.5 \%$. The definitions and samples for each code of students' knowledge about different elements are shown in Appendix D.

Thematic analysis (TA) was employed with a dual top-down and bottom-up approach for the qualitative data in our study in analysing interviews [57]. Similarly, three categories were constructed in the coding system based on the previous theoretical framework of genre knowledge. They are "formal knowledge", "process knowledge", and "rhetorical knowledge". Students' responses to interview questions were extracted into subcategories, ranging from "reflections of their knowledge", "sources of their presented knowledge", and "changes in knowledge", to "reasons of these changes", which were then placed into previous main categories. In coding the data, we shifted between the data and the coding system repeatedly. The coding systems of the semi-structured interview and previous questionnaire were compared as both instruments contributed to the exploration of participants' knowledge of argumentation. Two L2 writing experts, whose mother tongue is Chinese, were invited to appraise the coding scheme, with affirmative feedback and their questions and suggestions contributed to the data analysis process.

The argumentative written texts were assessed with reference to the structure and overall quality. The coding of students' argumentative writing structure was based on Toulmin's model [61], including claim, data, counterargument claim, counterargument data, rebuttal claim, and rebuttal data. The identification of these six elements was summarised based on indicator words, semantic structures, linguistic features, and prepositional phrases in students' text [62,63]. During this process, a coder and one of the authors used the rubrics to complete a structural analysis. Cohen's [64] Kappa was calculated to ensure the interrater reliability between these two coders. The inter-rater reliabilities were 0.92 (claim), 0.90 (data), 0.98 (counterargument claim), 0.95 (counterargument data), 0.96 (rebuttal claim), and 0.98 (rebuttal data), respectively, and the overall Cohen's Kappa was 0.95, indicating a satisfactory level of interrater reliability.

The overall score of each text was evaluated with a scoring scheme, in which we modified Glasswell et al.'s [65] asTTle marking rubrics (argue or persuade). The scoring rubric was identified from the following six aspects: "content inclusion" $(20 \%)$, "coherence" $(20 \%)$, "audience awareness and purpose" $(20 \%)$, "language resources for achieving the purpose" (20\%), "vocabulary and grammar" (15\%), and "mechanics" (5\%) (Appendix E). The inter-rater reliability between two raters for the overall writing scores was acceptable (coefficient alpha $=0.89$ ).

The data from the questionnaires and written texts were cleaned first. The assumptions of normality were run on the data before the statistical tests. In terms of knowledge elements, the category of language knowledge and process knowledge showed normal distribution; while the numbers of the rest of knowledge elements (structure knowledge, content knowledge, and rhetorical knowledge) were non-normally distributed. The textual data showed that the category of discourse moves, and overall scores were normally distributed.

Independent $t$-tests were applied to explore the differences between groups before and after the writing instruction. Paired-samples $t$-tests were used to investigate the differences 
within each group between Times 1 and 2. Cohen's $d$ was provided as the measure of effect sizes $($ small $=0.2$; medium $=0.5$; large $=0.8$ ) [58]. Mann-Whitney $U$ tests and Wilcoxon signed-rank tests were applied to compare the differences between and within the groups for the analysis of non-normal variables. The effect size, $r$, was used as indexes to report the magnitude (small $=0.10$; medium $=0.30$; large $=0.50$ ) [64]. In addition, a set of ANCOVAs with repeated measures was conducted to compare differences of the two groups of participants' discourse moves and overall qualities in their writing at Time two, controlling the capability of their writing performance between the two groups at Time one as a covariate. Partial eta square $\left(\eta^{2}\right)$ was reported as the magnitude of effect sizes (small $=0.01$; medium $=0.06$; large $=0.14$ ) [64]. Moreover, repeated-measures ANOVAs were conducted to determine whether there were statistically significant differences between the four groups after the writing instruction of participants' discourse moves and writing scores.

\section{Results}

\subsection{Comparison of Baseline Conditions of Different Groups at Time One}

4.1.1. Argumentative Knowledge

Tables 2 and 3 present the descriptive statistics of the students' knowledge of argumentation, as well as the corresponding results of the independent samples $t$-tests and Mann-Whitney $U$. The findings of knowledge in each group are reported according to the following three categories: formal knowledge, process knowledge, and rhetorical knowledge. The formal knowledge was further divided into the following three dimensions: structural knowledge, content knowledge, and language knowledge. Mann-Whitney $U$ and independent samples $t$-tests were conducted for the numbers of knowledge elements. Results revealed that there was no significant difference in students' knowledge of each element between the experimental and comparison groups in either the high- or low-proficiency groups at Time one.

Table 2. Descriptive statistics and independent samples $t$-tests of students' conceptualisation of the genre knowledge regarding "argumentation" between groups at Time 1.

\begin{tabular}{|c|c|c|c|c|c|c|c|c|}
\hline & & Proficiency & Group & $\mathbf{N}$ & $\mathbf{M}$ & SD & $t$ & $p$ \\
\hline \multirow{2}{*}{ Formal knowledge } & \multirow{2}{*}{ Language knowledge } & High & $\begin{array}{l}\text { Experimental } \\
\text { Comparison }\end{array}$ & $\begin{array}{l}18 \\
19\end{array}$ & $\begin{array}{l}1.20 \\
2.31\end{array}$ & $\begin{array}{c}0.837 \\
1.23\end{array}$ & -2.71 & 0.714 \\
\hline & & Low & $\begin{array}{l}\text { Experimental } \\
\text { Comparison }\end{array}$ & $\begin{array}{l}18 \\
19\end{array}$ & $\begin{array}{l}1.72 \\
1.83\end{array}$ & $\begin{array}{l}0.372 \\
0.473\end{array}$ & 0.488 & 0.936 \\
\hline \multirow{2}{*}{\multicolumn{2}{|c|}{ Process knowledge }} & High & $\begin{array}{l}\text { Experimental } \\
\text { Comparison }\end{array}$ & $\begin{array}{l}18 \\
19\end{array}$ & $\begin{array}{l}5.67 \\
5.33\end{array}$ & $\begin{array}{l}1.33 \\
1.20\end{array}$ & -0.471 & 0.637 \\
\hline & & Low & $\begin{array}{l}\text { Experimental } \\
\text { Comparison }\end{array}$ & $\begin{array}{l}18 \\
19\end{array}$ & $\begin{array}{l}4.67 \\
4.85\end{array}$ & $\begin{array}{l}0.882 \\
0.577\end{array}$ & -0.316 & 0.442 \\
\hline
\end{tabular}

Table 3. Results of Mann-Whitney $U$ tests of students' conceptualisation of the genre knowledge of "argumentation" between groups at Time 1.

\begin{tabular}{|c|c|c|c|c|c|c|c|c|}
\hline & & Proficiency & Group & $\mathbf{N}$ & $\mathbf{M}$ & SD & $z$ & $p$ \\
\hline \multirow{8}{*}{ Formal knowledge } & \multirow{4}{*}{ Structure knowledge } & \multirow{2}{*}{ High } & Experimental & 18 & 1.17 & 0.792 & \multirow{2}{*}{-0.677} & \multirow{2}{*}{0.498} \\
\hline & & & Comparison & 19 & 1.83 & 0.946 & & \\
\hline & & \multirow{2}{*}{ Low } & Experimental & 18 & 1.87 & 0.764 & \multirow{2}{*}{-0.303} & \multirow{2}{*}{0.799} \\
\hline & & & Comparison & 19 & 1.94 & 0.792 & & \\
\hline & \multirow{4}{*}{ Content knowledge } & \multirow{2}{*}{ High } & Experimental & 18 & 3.12 & 1.27 & \multirow{2}{*}{0.452} & \multirow{2}{*}{0.978} \\
\hline & & & Comparison & 19 & 2.57 & 1.54 & & \\
\hline & & \multirow{2}{*}{ Low } & Experimental & 18 & 1.83 & 0.749 & \multirow{2}{*}{-0.306} & \multirow{2}{*}{0.766} \\
\hline & & & Comparison & 19 & 2.17 & 0.792 & & \\
\hline \multirow{4}{*}{\multicolumn{2}{|c|}{ Rhetorical knowledge }} & \multirow{2}{*}{ High } & Experimental & 18 & 4.55 & 0.802 & \multirow{2}{*}{0.489} & \multirow{2}{*}{0.834} \\
\hline & & & Comparison & 19 & 4.01 & 0.775 & & \\
\hline & & \multirow{2}{*}{ Low } & Experimental & 18 & 2.82 & 0.784 & \multirow{2}{*}{-0.603} & \multirow[b]{2}{*}{0.546} \\
\hline & & & Comparison & 19 & 2.27 & 0.648 & & \\
\hline
\end{tabular}




\subsubsection{Writing Performance}

Table 4 reports the descriptive statistics of variables of the students' writing performance, as well as the corresponding results of the independent samples $t$-test. These variables include discourse moves and overall writing scores. Independent samples $t$-tests did not produce significant differences between the experimental- and comparison-high proficiency groups, and experimental- and comparison-low proficiency groups in terms of these two dimensions in their writing prior to the writing instructions.

Table 4. Results of the independent samples $t$-tests of discourse moves and overall writing scores between groups in the pre-test.

\begin{tabular}{|c|c|c|c|c|c|c|c|c|}
\hline & & Proficiency & Group & $\mathbf{N}$ & $\mathbf{M}$ & SD & $t$ & $p$ \\
\hline \multirow{24}{*}{ Discourse Moves } & \multirow{4}{*}{ Claim } & \multirow{2}{*}{ High } & Experimental & 18 & 1.05 & 0.372 & \multirow{2}{*}{0.227} & \multirow{2}{*}{0.821} \\
\hline & & & Comparison & 19 & 1.14 & 0.507 & & \\
\hline & & \multirow[b]{2}{*}{ Low } & Experimental & 18 & 1.20 & 0.401 & \multirow[b]{2}{*}{0.210} & \multirow[b]{2}{*}{0.852} \\
\hline & & & Comparison & 19 & 1.27 & 0.967 & & \\
\hline & \multirow{4}{*}{ Data } & \multirow[b]{2}{*}{ High } & Experimental & 18 & 1.79 & 1.096 & \multirow{2}{*}{0.535} & \multirow[b]{2}{*}{0.594} \\
\hline & & & Comparison & 19 & 1.98 & 1.105 & & \\
\hline & & \multirow{2}{*}{ Low } & Experimental & 18 & 1.41 & 1.015 & \multirow{2}{*}{-0.614} & \multirow{2}{*}{0.541} \\
\hline & & & Comparison & 19 & 1.87 & 1.056 & & \\
\hline & \multirow{4}{*}{ Counterargument Claim } & \multirow{2}{*}{ High } & Experimental & 18 & 0.78 & 0.522 & \multirow{2}{*}{0.350} & \multirow{2}{*}{0.727} \\
\hline & & & Comparison & 19 & 0.95 & 0.529 & & \\
\hline & & \multirow{2}{*}{ Low } & Experimental & 18 & 0.31 & 0.763 & \multirow[b]{2}{*}{0.324} & \multirow[b]{2}{*}{0.736} \\
\hline & & & Comparison & 19 & 0.21 & 0.587 & & \\
\hline & \multirow{4}{*}{ Counterargument Data } & \multirow{2}{*}{ High } & Experimental & 18 & 0.92 & 0.706 & \multirow{2}{*}{0.173} & \multirow{2}{*}{0.912} \\
\hline & & & Comparison & 19 & 0.95 & 1.27 & & \\
\hline & & \multirow{2}{*}{ Low } & Experimental & 18 & 0.55 & 0.767 & \multirow[b]{2}{*}{1.169} & \multirow[b]{2}{*}{0.245} \\
\hline & & & Comparison & 19 & 0.21 & 0.870 & & \\
\hline & \multirow{4}{*}{ Rebuttal Claim } & Hioh & Experimental & 18 & 0.56 & 0.465 & 0357 & 0723 \\
\hline & & 111" & Comparison & 19 & 0.50 & 0.534 & $0.35 \%$ & 0.723 \\
\hline & & & Experimental & 18 & 0.11 & 0.523 & & \\
\hline & & Low & Comparison & 19 & 0.07 & 0.587 & -0.361 & 0.719 \\
\hline & & Hioh & Experimental & 18 & 0.44 & 0.471 & & \\
\hline & & Hign & Comparison & 19 & 0.23 & 0.448 & 0.400 & 0.690 \\
\hline & Rebuttal Data & & Experimental & 18 & 0.02 & 0.392 & & \\
\hline & & Low & Comparison & 19 & 0.02 & 0.372 & 0.142 & 0.921 \\
\hline & & High & Experimental & 18 & 60.2 & 7.6 & & \\
\hline & Writing Scores & ngn & Comparison & 19 & 59.7 & 7.00 & 0.057 & 0.953 \\
\hline & Writing scores & & Experimental & 18 & 42.3 & 7.3 & & \\
\hline & & Low & Comparison & 19 & 42.5 & 7.1 & 0.030 & 0.976 \\
\hline
\end{tabular}

Taken together, the statistical results indicated that high- and low-proficiency students in the experimental and comparison groups were comparable with regard to the argumentative knowledge they had and the writing performance they demonstrated before the instructions started.

\subsection{Changes in Students' Argumentative Knowledge within and between Groups}

This section aims to present how the instruction affects students' knowledge in argumentation within and between different groups from numeric, substantial, and reflective directions.

4.2.1. Quantitative Differences in Students' Argumentative Knowledge within and between Groups

A series of paired-samples $t$-tests were used to compare the changes in the students knowledge of language features and process element between Times one and two within each group. The results in Table 5 show that students in the experimental high- and low-proficiency groups had a significant improvement in their conceptual argumentative language knowledge, and the effects of gains were large (Cohen's $d=0.869,836$ ). No significant change was detected in the comparison high- and low-proficiency groups in terms of their knowledge of language features in argumentative writing. As shown in 
Table 5, no significant changes in the students' knowledge of process element were found in all the groups between Times one and two.

Table 5. Results of the paired samples $t$-tests of students' conceptualisation of genre knowledge regarding "argumentation" within the groups.

\begin{tabular}{ccccccccc}
\hline \multirow{2}{*}{ Group } & \multirow{2}{*}{ Variables } & \multicolumn{2}{c}{ Pre-Test } & \multicolumn{2}{c}{ Post-Test } & \multirow{2}{*}{$\boldsymbol{t}$} & $\boldsymbol{p}$ & $\boldsymbol{d}$ \\
\cline { 3 - 6 } & & $\mathbf{M}$ & SD & $\mathbf{M}$ & SD & & & \\
\hline Experimental & Language knowledge & 1.83 & 0.374 & 3.782 & 0.691 & -2.991 & 0.040 & 0.869 \\
high proficiency $(n=18)$ & Process knowledge & 5.30 & 1.333 & 6.67 & 2.404 & -0.935 & 0.401 \\
\hline Comparison & Language knowledge & 1.68 & 0.548 & 3.00 & 1.166 & -0.677 & 0.498 \\
high proficiency $(n=19)$ & Process knowledge & 5.33 & 1.202 & 6.33 & 1.333 & -0.816 & 0.414 \\
\hline Experimental & Language knowledge & 1.80 & 0.374 & 4.00 & 0.949 & -2.491 & 0.045 & 0.836 \\
low proficiency $(n=18)$ & Process knowledge & 4.67 & 0.882 & 5.87 & 1.732 & -0.854 & 0.403 \\
\hline Comparison & Language knowledge & 1.80 & 0.374 & 2.00 & 0.837 & -0.272 & 0.785 \\
low proficiency $(n=19)$ & Process knowledge & 4.54 & 0.577 & 5.10 & 1.528 & -0.321 & 0.936 \\
\hline
\end{tabular}

Wilcoxon signed-rank tests were conducted for comparing students' conceptualisations of knowledge of structural, content, and rhetorical elements within each group. The findings in Table 6 revealed a significant improvement in the students' structural knowledge at Time two than the Time one for both the high and low experimental groups $(z=-2.732, p<0.05, r=0.739 ; z=-2.687, p<0.05, r=0.654)$ with a large effect size. No significant change was found in the comparison high- and low- proficiency groups in structural, content, or rhetorical elements.

Table 6. Results of Wilcoxon signed-rank tests of students' conceptualisation of the genre knowledge regarding "argumentation" within the groups.

\begin{tabular}{|c|c|c|c|c|c|c|c|c|}
\hline \multirow{2}{*}{ Group } & \multirow{2}{*}{ Variables } & \multicolumn{2}{|c|}{ Pre-Test } & \multicolumn{2}{|c|}{ Post-Test } & \multirow{2}{*}{$z$} & \multirow{2}{*}{$p$} & \multirow{2}{*}{$r$} \\
\hline & & $M$ & $S D$ & $M$ & $S D$ & & & \\
\hline \multirow{3}{*}{$\begin{array}{c}\text { Experimental } \\
\text { high proficiency }(n=18)\end{array}$} & Structural knowledge & 1.17 & 1.941 & 4.67 & 1.141 & -2.732 & 0.042 & \multirow[t]{3}{*}{0.739} \\
\hline & Content knowledge & 3.17 & 1.249 & 4.67 & 1.054 & -0.954 & 0.340 & \\
\hline & Rhetorical knowledge & 2.91 & 0.791 & 4.55 & 0.802 & -1.228 & 0.219 & \\
\hline \multirow{3}{*}{$\begin{array}{c}\text { Comparison } \\
\text { high proficiency }(n=19)\end{array}$} & Structural knowledge & 1.83 & 2.317 & 3.00 & 2.683 & -2.150 & 0.084 & \\
\hline & Content knowledge & 3.17 & 1.327 & 3.45 & 1.447 & -0.321 & 0.936 & \\
\hline & Rhetorical knowledge & 2.82 & 0.711 & 3.54 & 0.775 & -0.897 & 0.356 & \\
\hline \multirow{3}{*}{$\begin{array}{c}\text { Experimental } \\
\text { low proficiency }(n=18)\end{array}$} & Structural knowledge & 1.50 & 1.871 & 4.47 & 1.472 & -2.687 & 0.045 & \multirow[t]{3}{*}{0.654} \\
\hline & Content knowledge & 1.83 & 0.749 & 3.17 & 0.792 & -0.843 & 0.399 & \\
\hline & Rhetorical knowledge & 2.81 & 0.784 & 4.00 & 0.381 & -1.181 & 0.237 & \\
\hline \multirow{3}{*}{$\begin{array}{c}\text { Comparison } \\
\text { low proficiency }(n=19)\end{array}$} & Structural knowledge & 1.94 & 0.792 & 2.36 & 0.966 & -1.941 & 0.110 & \\
\hline & Content knowledge & 1.76 & 0.792 & 2.67 & 1.085 & -1.134 & 0.457 & \\
\hline & Rhetorical knowledge & 2.27 & 0.648 & 3.43 & 1.044 & -1.167 & 0.267 & \\
\hline
\end{tabular}

As shown in Table 7, the results from independent samples $t$-tests showed significant differences between the experimental and comparison high-proficiency groups at Time two in their language knowledge $(t(37)=-2.108, p<0.05$, Cohen's $d=0.659)$ and between the experimental and comparison low-proficiency groups $(t(37)=-2.073, p=0.042$, Cohen's $d=0.745$ ). The results also demonstrated that the experimental high-proficiency and lowproficiency groups outperformed their counterparts in the comparison group due to the genre-based approach, with a medium effect size on the language knowledge elements. The experimental and comparison groups, however, did not statistically differ in their process knowledge, $t(37)=-0.221, p=0.825 ; t(37)=-0.157, p=0.801$. 
Table 7. Results of the independent samples $t$-tests of students' conceptualisations of genre knowledge of "argumentation" between groups at Time 2 .

\begin{tabular}{|c|c|c|c|c|c|c|c|c|}
\hline & & Proficiency & Group & $\mathbf{N}$ & $\mathbf{M}$ & SD & $t$ & $p$ \\
\hline \multirow{4}{*}{ Formal knowledge } & \multirow{4}{*}{ Language knowledge } & \multirow{2}{*}{ High } & Experimental & 18 & 3.782 & 0.691 & \multirow{2}{*}{-2.108} & \multirow{2}{*}{0.035} \\
\hline & & & Comparison & 19 & 2.10 & 1.166 & & \\
\hline & & \multirow{2}{*}{ Low } & Experimental & 18 & 4.00 & 0.949 & \multirow{2}{*}{-2.073} & \multirow{2}{*}{0.042} \\
\hline & & & Comparison & 19 & 2.00 & 0.837 & & \\
\hline \multirow{4}{*}{\multicolumn{2}{|c|}{ Process knowledge }} & \multirow{2}{*}{ High } & Experimental & 18 & 6.67 & 2.404 & \multirow{2}{*}{-0.221} & \multirow{2}{*}{0.825} \\
\hline & & & Comparison & 19 & 6.33 & 1.333 & & \\
\hline & & \multirow{2}{*}{ Low } & Experimental & 18 & 5.87 & 1.732 & \multirow{2}{*}{-0.157} & \multirow{2}{*}{0.801} \\
\hline & & & Comparison & 19 & 5.10 & 1.528 & & \\
\hline
\end{tabular}

As presented in Table 8, the results from the Mann-Whitney $U$ tests further revealed that the students in the experimental high- and low-proficiency groups gained significantly stronger development in structure knowledge $(\mathrm{M}=4.67, \mathrm{SD}=1.141 ; \mathrm{M}=4.17, \mathrm{SD}=1.472)$ than the students in the comparison high- and low-proficiency groups $(\mathrm{M}=3.00, \mathrm{SD}=2.683$; $\mathrm{M}=2.36, \mathrm{SD}=0.966) ; z=-2.067$, and $-2.023 ; p<0.05, r=0.34$, and 0.33) with medium effect sizes.

Table 8. Results of Mann-Whitney $U$ tests of students' conceptualisations of genre knowledge regarding "argumentation" between groups at Time 2 .

\begin{tabular}{|c|c|c|c|c|c|c|c|c|}
\hline & & Proficiency & Group & $\mathbf{N}$ & $\mathbf{M}$ & SD & $z$ & $p$ \\
\hline \multirow{7}{*}{ Formal knowledge } & \multirow{3}{*}{ Structure knowledge } & \multirow[t]{2}{*}{ High } & Experimental & 18 & 4.67 & 1.141 & \multirow{2}{*}{-2.067} & \multirow{2}{*}{0.041} \\
\hline & & & Comparison & 19 & 3.00 & 2.683 & & \\
\hline & & Low & $\begin{array}{l}\text { Experimental } \\
\text { Comparison }\end{array}$ & $\begin{array}{l}18 \\
19\end{array}$ & $\begin{array}{l}4.17 \\
2.36\end{array}$ & $\begin{array}{l}1.472 \\
0.966\end{array}$ & -2.023 & 0.040 \\
\hline & \multirow{4}{*}{ Content knowledge } & \multirow{2}{*}{ High } & Experimental & 18 & 4.67 & 1.054 & \multirow{2}{*}{-0.969} & \multirow{2}{*}{0.332} \\
\hline & & & Comparison & 19 & 3.45 & 1.447 & & \\
\hline & & \multirow{2}{*}{ Low } & Experimental & 18 & 3.17 & 0.792 & \multirow{2}{*}{-0.405} & \multirow{2}{*}{0.686} \\
\hline & & & Comparison & 19 & 2.67 & 1.085 & & \\
\hline \multirow{4}{*}{\multicolumn{2}{|c|}{ Rhetorical knowledge }} & \multirow{2}{*}{ High } & Experimental & 18 & 4.55 & 0.802 & \multirow{2}{*}{-0.397} & \multirow{2}{*}{0.692} \\
\hline & & & Comparison & 19 & 3.54 & 0.775 & & \\
\hline & & \multirow{2}{*}{ Low } & Experimental & 18 & 4.00 & 0.381 & \multirow{2}{*}{-0.099} & \multirow{2}{*}{0.921} \\
\hline & & & Comparison & 19 & 3.43 & 1.044 & & \\
\hline
\end{tabular}

\subsubsection{Evidence of Changes in Students' Argumentative Knowledge after the Instruction}

Qualitative content analysis of the codes regarding the students' structural knowledge showed that at Time one, Chinese EFL students generally had a poor understanding of argumentation with vague descriptions with "introduction-body-conclusion" (IBC), which suggested a lack of specific understanding of the genre. At Time two, after the genre-based writing course, they increased their understanding of the genre in sub-categories, "introductionthesis-argument-counterargument-evaluation" (ITAC) and "thesis-evaluation-conclusion" (TEC), which indicated more identifications of argument, counterargument, and evaluation, relating to the generic meaning of argumentation. An indicator of content knowledge development at the substance level is that, whereas almost all the students who responded to the question on the argument content at Time one with only general comments, such as "contrast different arguments" and "prove my viewpoint with examples"; at Time two, a few experimental high-proficiency students explained their "argument" content as "citing accurate data", "the readable reasons", and "critique authorities". In other words, after the genre-based instruction, some students demonstrated their understanding of the argument content by highlighting the purpose of the argumentative writing and the relationship between the content and the reader. The comparison group, however, showed no such change. In the pre-instruction phase, students' language knowledge concentrated 
on "advanced vocabulary" and "linking words", without any consideration of the context of argumentation, while at Time two, the experimental group students used more specific words, such as "reporting verbs", "words of praises and critiques", and "words of evaluation". These results demonstrated that the experimental group students provided more details about the knowledge interaction between formal and rhetorical elements at Time two than at Time one, whereas no significant changes were found in the comparison group.

The content analysis of the codes "classifying" and "gathering" regarding students" process knowledge showed that these students only demonstrated their composing process in a simpler way, that is, they only aggregated their argumentative reasons at Time one. At Time two, some experimental students described more about the code of "evaluating", which indicated that they realised writing to be a complex composing process, which included understanding, summarising, gathering, as well as evaluating. The comparison group did not show similar changes in their understanding of the knowledge of argumentation after the conventional writing instruction.

At the rhetorical level, the experimental group students had greater consideration of the reader and the context of the argumentation after the instruction. For example, the subcategory of "writer-reader interactions" included more critical analysis of their audience at Time two. That is, the experimental high-proficiency group students' comments on "writer-reader interactions" progressed from merely "letting the reader know my viewpoint", "letting the reader assert my position", and "strengthening the persuasion", to "identifying readers' possible claim" and "finding out your readers" weakness". The unit of the writing course, "purposes of arguing", focused more on "my viewpoint", "my writing level", "Chinese education culture", "my experience", and "the topic" at Time one, while at Time two, it included a greater focus on the reader, including "persuading the reader" and "the correctness of statements". Furthermore, for the code of "writer-content interactions", the experimental high-proficiency group students' voices suggested a deeper level of understanding of the features of argumentation after the genre-based writing teaching. The participants' descriptions of their writing content in argumentation implied greater rhetorical awareness at Time two. For example, their comments changed from "unifying examples with my viewpoint", "letting the readers know my viewpoint", and "being accurate and using word and grammar efficiently", to "working on the understandability of reasons", "addressing the reliability of the examples", and "how to make objective examples". The comparison group did not show such changes.

\subsubsection{Students' Reflections on Changes in Their Knowledge after the Instruction}

Several experimental group students pointed out that the teacher's genre-based teaching in argumentation expanded their understanding of the formal knowledge, including the structure, language, and content in argumentation. Two students reported that the moves of counterargument and evaluation were needed to ensure a specific purpose rather than a general narration of their argument (Ann, Tom). Two students commented on what they had gained in the content explanations and evaluative language in argumentation. One student pointed out that "it is very hard for me to find more effective evidence to prove my claim. However, I know that I should think about the accuracy of data and how to make my reasons readable" (Jane). One student acknowledged that "the teacher helped us build a writing model of argumentation with various language feature for arguing, persuading, evaluating, and discussing. I gradually understood that I had to use words accurately in praising, criticising, arguing, and evaluating my writing" (Ella). In contrast, only one comparison group student indicated that he began to concentrate on the sentence logic in writing after the writing course (George). In addition, the comparison group students did not reflect on their writing moves and writing content in argumentation.

Several experimental group students also commented on their organised procedures and rhetorical purposes in argumentation as well as their relationships with the genrebased instruction. With regard to the growth in their process knowledge of argumentation, one experimental group participant explained that her changes were attributed to the 
practice of teacher-led "writing model" construction. In contrast, in the initial stage, she described the process with only one procedure, "finding a couple of examples", and after the writing intervention, she began to record a complex series of steps (e.g., read and understood the prompt, summarised the basic arguments in the reading, classified and gathered resources, and evaluated these things from argument and counterargument viewpoints" (Jane). Such comments and reflections by the experimental group students showed that these students acquired more information about the interactions among formal knowledge, process knowledge, and rhetorical knowledge after the writing instruction. With regard to the students' growth in rhetorical knowledge of argumentation, many experimental group participants stated their development. That is, they were not clear of the aim of the argumentation, which was "for expressing my ideas about this topic" (Ann) and that they "never paid attention to the argument or the reader" (Tom). One student pointed out that while she was not satisfied with her ignorance of the audience in her writing before the instruction, after the teacher-led practice, she was more considerate of her readers, commenting that, "the consideration of readers' needs is important for English argumentative writing, although I have never paid attention to it before. After the examples during the class, the use of convincing evidence to persuade someone is needed. I should think about what they already thought" (Jane). At Time two, another experimental group student (Tom) also reported that "I gradually realise that writers need to convey a clear perspective and evidence to the various readers, such as experts, authorities, or general audiences, who are persuaded with what they already thought in a context, not just describing personal perspectives". The comparison group students also reflected on the changes in their knowledge of the process and rhetorical elements after the conventional writing course, but their changes were not as obvious as those of the experimental group. For example, one comparison group student recommended that "I did not do any planning before; I just followed my thought and tried to translate my Chinese ideas into English. While after the writing course, I will classify examples with reference to their uses, i.e., the pros and cons of these sentences, which rely on the topic I will be writing about" (Grace). Another comparison group student claimed that "after the writing course, I learned to pay more attention to other possible claims, while I have never paid attention to readers' perceptions before" (David).

\subsection{Changes in Students' Writing Performance within and between Groups}

The importance of how the instruction affects students' writing performance in argumentation was a key consideration in our study. We report findings below by examining the within- and between-group differences in discourse moves and the students' overall scores as indicators of their writing improvement.

\subsubsection{Changes in Discourse Moves}

A series of paired samples $t$-tests were applied to compare the discourse moves in the pre- and post-tests within each group. As presented in Table 9, the experimental high- and low-proficiency students showed similar improvement in all structural elements. Specifically, there were slight increases in three elements, including claim, data, and rebuttal data, and these increases were not statistically significant $(p>0.05)$. However, they had statistically significant gains in the other three argumentative moves: counterargument claim $(p<0.05)$, counterargument data $(p<0.05)$, and rebuttal claim $(p<0.05)$. For the comparison group, as shown in Table 9, the high-proficiency students showed gains in three elements, including counterargument claim, rebuttal claim, and rebuttal data. However, none of these moves had significantly improved. In contrast, the low-proficiency students demonstrated significant gains in only one argumentative element, counterargument claim $(p<0.05)$.

A series of repeated-measures ANOVAs revealed significant differences in the students gains in discourse moves between the four groups. The results demonstrated that there were significant differences among these four groups in the means of "counterargument 
claim" $(\mathrm{F}(3,70)=18.83, p<0.05)$ and "counterargument data" $(F(3,70)=9.7, p<0.05)$ from Time one to Time two. The post hoc sidak test further found significant differences in the moves of "counterargument claim" and "counterargument data" between the experimental high-proficiency group and the comparison high-proficiency group $(p<0.05)$, suggesting that the impact of the genre-based writing method was greater than the impact of the conventional writing approach on the high-proficiency students' use of "counterargument claim" and "counterargument data" in argumentative writing. The other four elements, however, did not show statistically significant differences between Times one and two among the four groups.

Table 9. Differences in discourse moves and overall writing scores of the high and low experimental and the comparison groups in the pre- and post-tests.

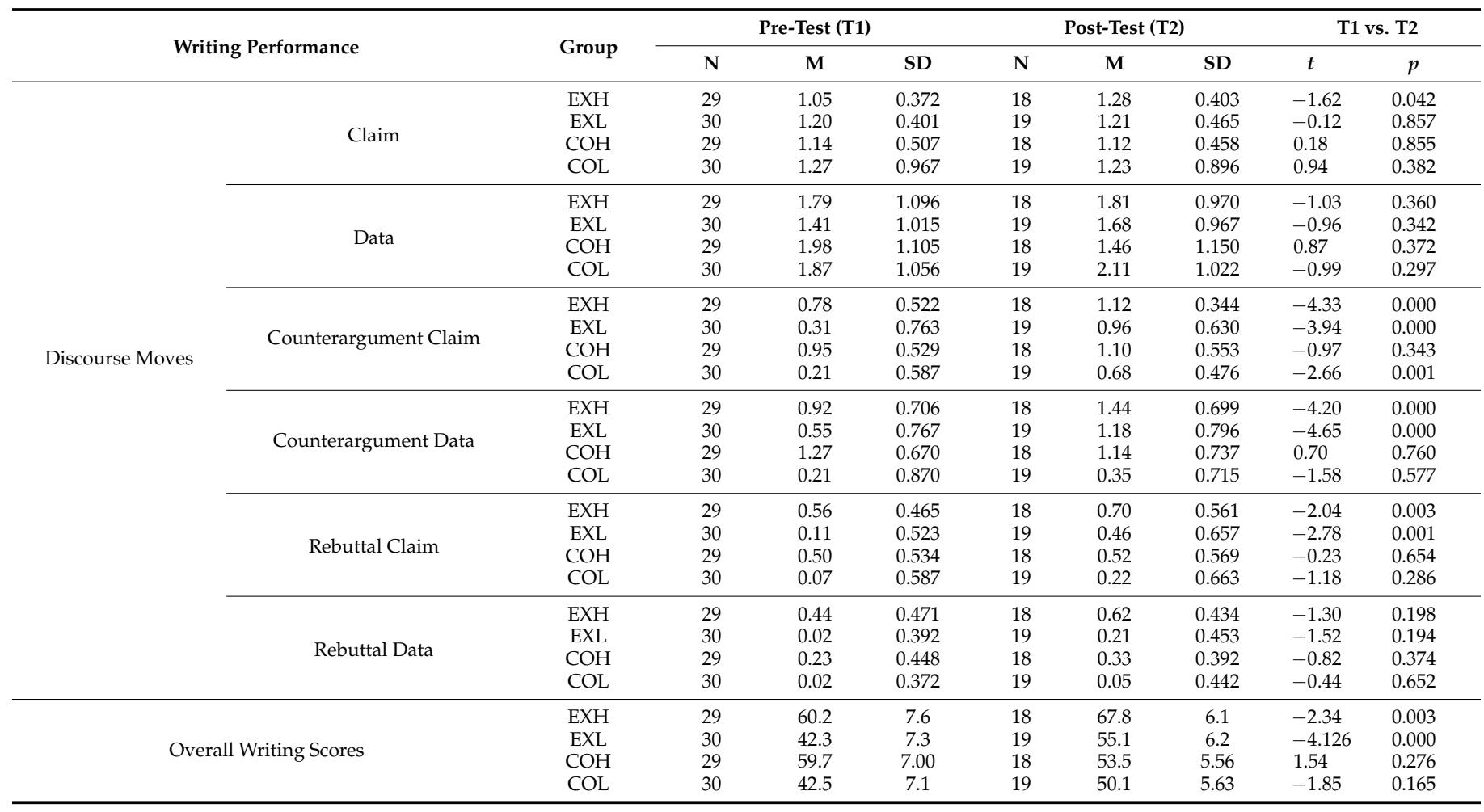

\subsubsection{Changes in Overall Writing Scores}

As shown in Table 9, a series of paired samples $t$-tests revealed that the students from the high-proficiency $(p<0.05)$ and the low-proficiency $(p<0.05)$ experimental groups had significant gains in the overall writing score from Time one to Time two. The comparison group students showed a different pattern in the overall writing quality, with the lowproficiency students demonstrating an increase, while the high-proficiency students had a decrease in the writing scores after the conventional writing course.

The results of the repeated-measures ANOVA were used to determine whether there were statistically significant differences between the students' overall writing scores among the four groups at Time one and Time two. The results showed a significant difference among these four groups $[F(3,70)=24.19, p<0.05]$. The post hoc sidak test showed that the difference was statistically significant between the comparison high-proficiency group and the experimental low-proficiency group $(p=0.003)$.

\section{Discussion}

We examined the usefulness of an eight-week genre-based writing instruction and found the development in terms of Chinese EFL undergraduates' argumentative knowledge and writing performance. Overall, the experimental high and low proficiency groups 
outperformed the comparison high and low proficiency groups in their development of knowledge of argumentation and improvement in argumentative writing.

\subsection{Effects on Students' Argumentative Knowledge}

The students' argumentative knowledge at the formal level included three types of focused dimensions (structural knowledge, language knowledge, and content knowledge). It is reported that the genre-based approach contributed more to developing the students' formal knowledge, particularly the structure and language knowledge, than the conventional teaching method. These positive changes suggest that the explicit genre-based pedagogy appeared to have raised the students' knowledge of argumentation, especially in aspects such as discourse structures and language features, which was empirically evidenced in previous L2 writing studies $[30,35,52]$. In addition, several scholars pointed out that students' gains in knowledge of the content element of specific genres were not easy to achieve $[32,35,66]$. For example, Wette [35] posited that students' understanding of structural and language knowledge was not difficult with genre-based instruction but acquiring an understanding of content knowledge puts greater demands on students' cognitive ability because it requires an awareness beyond a single textual level. Our results also revealed that only the genre-based approach contributed more to the students' knowledge interaction between formal and rhetorical elements than the conventional method. The descriptions of aggregated knowledge of the formal and the rhetorical elements are a high-level knowledge form. As Yasuda [34] argued, only when linguistic and structural elements are integrated with rhetorical awareness in a specific genre can students use the knowledge about these two elements in their writing.

Regarding the effects on the students' knowledge about the process and rhetorical elements, no significant differences were found between the groups after different writing instructions in (1) the students' statements of their composing process in achieving the planned rhetorical action in a writing task, (2) their understanding of the purpose of a genre in a local context, (3) sophisticated awareness of audiences' beliefs, or (4) awareness of situated variables in different social contexts. The limited development of process knowledge aligns with the findings of Benesch's [67] and Jwas' [68] investigations in college level students' writing. They argued that undergraduates' process knowledge was hard to improve in a classroom-based writing intervention because in teachers' teaching and students' assessment of writing more attention was paid to surface features of the texts rather than the procedures students experienced during the writing task (see also [1,5,69] for recent discussions). The EFL students in our study perceived writing as a test and to them the purpose of writing was to obtain good scores guided by the grading criteria. Therefore, their limited understanding of the writing process and slow development is not unexpected. The results of the participants' limited change in the rhetorical element aligns with what was reported by Yasuda [31] and Negretti [70]. Both reported on L2 students' development of rhetorical awareness and supported the view that changes in L2 students' rhetorical knowledge in language-focused instruction takes time. We, thus, anticipate that if teachers simply focus on the teaching of linguistic and structural knowledge in a writing course, no significant effect will be shown in EFL students' development of writing knowledge with socialized thinking. Given that our results also revealed a stronger positive effect of the genre-based writing treatment on the experimental group students' knowledge interaction among formal, process, and rhetorical levels in argumentation, we think that these findings serve to lend support to previous studies on the developmental pattern of students' process and rhetorical knowledge [69,71]. That is, students' process knowledge is derivative, and its development is highly coordinated with other knowledge dimensions [68]. L2 writers' rhetorical knowledge improvement is correlated positively with organisational structures [72], language knowledge [31,71], and process knowledge [36]. Therefore, we recommend that EFL college freshmen be offered instruction in general academic genres and that this needs to be followed up with instruction in discipline-specific genres at a subsequent stage. 
The participants' reflections indicated that these teaching strategies contributed to develop a cooperative academic environment, which helped students to engage in the genre-based practices in promoting their argumentative knowledge gradually. According to Yasuda [31] and Negretti [70], the genre-based TLC is a type of instructional strategy, whereby teachers analyse textual models in a specific genre, encourage students to demonstrate their model analysis abilities in various contexts, and help them build their personal writing model. Wette [35] also reported that L2 students listed several benefits from teacher-guided activities of genre-related questions about different knowledge elements.

An important finding from our study is that the students' L2 writing proficiency played important roles in influencing the students' development of genre knowledge about different elements to varying degrees. More importantly, the genre-based approach contributed to a significant development in the students' formal knowledge, even for the students with a low writing proficiency. Such results seem in line with Kutteva and Negrettis' [66] conclusion that L2 students with a low language proficiency can possess formal knowledge after the genre-based instructional practices. Although their study was based on L2 writing in natural sciences, the results appear to resonate with ours.

\subsection{Effects on Students' Writing Improvement}

The experimental high- and low- proficiency groups significantly outperformed the comparison high- and low-proficiency groups students' developments in discourse moves of counterargument claim and counterargument data, and overall writing quality with medium effect sizes, as shown in the post-test. This reveals the positive effects of the genrebased instruction on writing improvement, as reported in L2 writing studies [29,31,34,52]. We could conclude that the genre-based approach helped the experimental group students to improve more in argumentative writing than those who did not receive genre-based instruction. For the developmental nature of the students' writing improvement, we also found that the intervention helped the experimental students to realise that they needed to focus on how to advance the essential information of an "argument" in each knowledge element; meanwhile, they seemed to be able to apply that knowledge fluently in their argumentative writing. Such a finding indicates the necessity to develop students' knowledge about different elements in specific genres in the writing course to sustain this positive influence, as many researchers have advised [26,34,52,73]. The changes in the high-proficiency students' overall writing improvement are not as obvious as in the low-proficiency students after the writing instruction in both the experimental and the comparison groups. This finding suggests that the high-proficiency students' statistically significant improvement in the overall writing quality during the short term of the intervention was not as obvious as it was for the low-proficiency group due to their relatively higher proficiency. This also suggests that a bigger gain in writing scores requires a longer time to take effect for a high-proficiency group. Therefore, a longer duration of intervention is needed.

\section{Conclusions}

This quasi-experiment research was used to explore the effects of genre-based writing instruction on students' knowledge development and writing improvement in the EFL writing classroom. Our findings show that the intervention successfully developed the students' knowledge of argumentation, fostered their reflections on the knowledge they had, and helped to improve their writing performance. These are encouraging findings that provide evidence for proposing pedagogical practices that can help the sustainable development of academic writing skills.

As a group of experts have argued, there is a need for implementing genre-based instruction in academic writing education $[32,34,38,43]$. Furthermore, our research provides empirical evidence for the effectiveness of such genre-based instruction to develop undergraduate students' genre knowledge about argumentation, as well as enhance their argumentative writing quality. After the genre-based intervention, the participants showed 
progress in the way they displayed their knowledge of structural and language features specific to the argumentation genre, the ways they reflected their knowledge of argumentation, and their written structure in argumentation, such as counterargument claims and counterargument data. However, it also showed that the intervention had a limited influence on their expressed knowledge about the content, process, and audience awareness in argumentation, and their written structure, such as rebuttal data in argumentation. All this means that an extension of genre-based teaching is needed to scaffold learners in these aspects. Our findings also provide evidence in support of teaching writing in consideration of students' individual differences.

The existing findings of the current study have some pedagogical implications. Firstly, our results suggest that genre-based writing practices are beneficial in facilitating students' argumentative writing learning at the tertiary level in China. Specifically, the teacher-led genre-based textual modelling and teacher-guided analysis of exemplars developed the learners' willingness to engage in a specific genre in argumentative writing. In addition, for curriculum design, our study suggests that writing instructors in the EFL classroom contexts could create teaching conditions that ensure opportunities for students to engage gradually with specific genres. That is, in the early stage, Chinese EFL college freshmen could be instructed in disciplinary genres as they have not entered into professional fields at this stage. Interventions with specific genre-based writing practices in students' disciplinary genre should be conducted in the subsequent stages [74].

Similar to many studies, our study is not exempt from limitations. One limitation is that the questions in the open-ended questionnaires and interviews are not an exhaustive list of students' genre knowledge from all the dimensions, especially their knowledge of the subject element. The list of questions was designed mainly in consideration of Chinese EFL students' needs at large. These non-English major sophomores in China were in specific situations different from other research contexts, which was where their disciplinary learning was situated in the primary stage. They did not need to write course papers or course assignments in English, either. As a result, our exploration of these students' genre knowledge of the elements in argumentation was limited. Therefore, in future studies, the exploration of the elements of Chinese EFL students' subject knowledge about argumentation needs to be extended. Students' experiences in learning to write in English for academic purposes can be approached from the perspectives of metacognitive knowledge and strategies-based instruction [75-77]. Another limitation is that this study lasted for only eight weeks; implementation of a longer intervention programme might achieve different results. Future studies might need to be longitudinal in research design in order to explore the dynamic development of Chinese EFL students' knowledge and writing performance in argumentation at different educational stages or across various majors among university students. In addition, in our study, the participants' writing proficiency was measured only once in the first writing test. A more reliable and holistic assessment of students' writing proficiency based on a number of writing tasks might be a better assessment of their composite proficiency.

Author Contributions: T.Z. and L.J.Z. conceived of and designed the study. T.Z. collected and analysed the data and wrote the first draft. L.J.Z. rewrote the subsequent drafts. All the authors revised the manuscript before L.J.Z. finalised and submitted it as the corresponding author. All authors have made substantial, direct, and intellectual contributions to the work, and approved it for publication. All authors have read and agreed to the published version of the manuscript.

Funding: This work did not receive any funding.

Institutional Review Board Statement: The study was conducted according to the guidelines of the Declaration of Helsinki, and approved by the Human Participants Ethics Committee of the University of Auckland (017467, June 2016).

Informed Consent Statement: Informed consent was obtained from all subjects involved in the study. 
Data Availability Statement: The original contributions presented in the study are included in the article, further inquiries can be directed to the corresponding author.

Conflicts of Interest: The authors declare that the research was conducted in the absence of any commercial or financial relationships that could be construed as a potential conflict of interest.

\section{Appendix A. Open-Ended Questionnaire}

\begin{tabular}{|c|c|c|}
\hline & Open-Ended Questions & Knowledge \\
\hline 1 & How would you describe the overall structure of your writing? & Formal knowledge \\
\hline 2 & Why did you choose this organisational pattern/structure? & Formal knowledge \\
\hline 3 & How would you present/define/express each structure? (What is the main content of each structure? & Formal knowledge \\
\hline 4 & In your opinion, what linguistic features will be used to express your ideas in argumentative writing? & Formal knowledge \\
\hline 5 & How do you compose this argumentation (write more about your composing process)? & Process knowledge \\
\hline 6 & In your opinion, what is the aim of your argumentative writing? & Rhetorical knowledge \\
\hline 7 & $\begin{array}{l}\text { Did you consider what kind of explanation is needed for the reader to understand the knowledge in } \\
\text { your writing? For example, what kind of things do you think about when you do your } \\
\text { argumentative writing? }\end{array}$ & Rhetorical knowledge \\
\hline 8 & Did you think about the reader's expectations from your argumentative writing? If yes, what are they? & Rhetorical knowledge \\
\hline
\end{tabular}

\section{Appendix B. Semi-Structural Interview}

Interview Questions (Pre-)

1. Did your teacher teach you any writing skills? If yes, do you think these skills are useful? Why?

老师在课堂中有教授过写作方法，技巧吗? 如果有，你认为这些技巧有用吗? 为什么?

2. Do you have any difficulties when you build the structure of your writing in the argumentative writing tasks? If yes, how do you solve these problems? 在写作任务中, 在搭建文章结构时有什么困难吗? 如果有, 你是如何解决的?

3. When you organise the content of your writing what were the key factors? Do you have any difficulties in this process? If yes, how do you solve these problems? 在构思文章内容时从哪些方面着手? 有遇到困难吗? 如果有, 如何解决?

4. What kinds of factors may influence your writing performance? 在进行写作时, 你认为自己的写作会受到哪些因素的影响?

5. Is language ability a barrier in your writing performance? If yes, what kinds of language factors may influence your writing performance? 语言 是你写作表达的障碍吗? 如果是, 你认为哪些语言因素会影响你的英文议论文写作?

6. When you were given an argumentative writing task, what did you do firstly? Why? 当拿到议论文任务时, 你首先会做什么?

7. Do you have any special aims in the recent argumentative writing practice? 现阶段进行的议论文写作练习中, 写作目的是什么?

8. Do you ever think about the reader of your argumentation? If yes, are there any special things you do to complete their demand? 有考虑过你的 议论文读者是谁吗? 如果有, 要满足读者的要求要做什么吗?

Interview Questions (Post-)

1. How would you evaluate your argumentative writing? Do you feel you have improved after the writing course? Why or why not? If yes, in what aspects? 如何评价自己的议论文写作? 写作课后有进步吗? 为什么? 如果有, 哪些方面有进步?

2. Did your teacher teach you any writing skills in the course? If yes, do you think these skills are useful to improve your writing? Why? 老师在写 作课上有教授写作方法, 技巧吗? 如果有, 你认为这些技巧可以帮助你提升写作吗? 为什么?

3. Do you have any difficulties when you build the structure of your writing in the argumentative writing tasks? If yes, how do you solve these problems? 在写作任务中, 在搭建文章结构时有什么困难吗? 如果有, 你是如何解决的? 写作课后有进步吗? 为什么?

4. When you organise the content of your writing, what were the key factors? Do you have any difficulties in this process? If yes, how do you solve these problems? Do you feel you have improved after the writing course? 在构思文章内容时从哪些方面着手? 有遇到困难吗? 如果有, 如何解 决? 写作课后有什么不同吗?

5. What kinds of factors may influence your writing performance? Do you feel you have improved after the writing course? 在进行写作时, 你认为 自己的写作会受到哪些因素的影响? 写作课后有什么不同吗?

6. Is language ability a barrier in your writing performance? If yes, what kinds of language factors may influence your writing performance? Do you feel you have improved after the writing course? 语言是你写作表达的障碍吗? 如果是, 你认为哪些语言因素会影响你的英文议论文写作? 写作 课后有什么不同吗?

7. When you were given an argumentative writing task, what did you do firstly? Why? Do you feel you have improved after the writing course during this process? 当拿到议论文任务时, 你首先会做什么? 写作课后有什么不同吗?

8. Do you have any special aims in the recent argumentative writing practice? Do you feel you have improved after the writing course in this section? 现阶段进行的议论文写作练习中, 写作写作目的是什么? 写作课后有什么不同吗?

9. Do you ever think about the reader of your argumentation? If yes, are there any special things you do to complete their demand? Do you feel you have improved after the writing course in this section? 有考虑过你的议论文读者是谁吗? 如果有, 要满足读者的要求要做什么吗? 写作课后有什 么不同吗? 


\section{Appendix C. Writing Prompts}

Appendix C.1. Writing Task (A)

One university student's suggestion on being allowed to focus on subjects in their first year at university:

Academically, we should take same courses that are decided by the government in the fresh year. However, for university students, I think we should be allowed to fully develop our preferred subjects in the first year. If all the students take the same courses, many talented students may feel frustrated with learning and the nation will not get the talent it needs for its advancement.

The task instructions are as follows:

Write an article responding to this student's suggestion about university curriculum reform. You may argue FOR or AGAINST his/her position, but your text should describe both argument and counterargument.

\section{Appendix C.2. Writing Task (B)}

One university teacher's suggestion on postgraduate stage English education:

For years, most English educators have only focused on generally fundamental knowledge in order to improve students' comprehensive English ability. However, for postgraduate student, once they acquired the basic general English knowledge, we should put language in a context to improve their language application ability, especially, in their selected professional field.

The task instructions are as follows:

Write an article responding to this teacher's suggestion about English instruction in postgraduate level. You may argue FOR or AGAINST his/her position, but your text should describe both argument and counterargument.

\section{Appendix D. The Definitions and Samples for Each Code of Students' Knowledge about Different Elements}

(1) Structure knowledge: six categories of codes ("introduction-body-conclusion"; " problemsolution"; "thesis-argument"; "claim-counterargument claim-evaluation"; "introductionthesis-argument-counterargument-evaluation"; and "thesis-evaluation-conclusion") were recognised.

(2) Language knowledge: three categories of codes ("lexis", "syntax", and "grammar") were aggregated. The code "lexis" contained the students' statements about the use of vocabulary in their wiring. For example, their answers of "reporting verbs", "words of praise and critique", "words of evaluation", "attitude labels", and "conjunctions", were in this code. The code "syntax" included the students' answers referring to their use of sentence patterns in the writing. For example, "subordinate clause", "complex sentence", and "participle structure". The code "grammar" contained the students" statements about their consideration of grammar rules. For example, "my grammar is poor, and I cannot express myself well with accurate grammar", "I cannot use proper grammar in my writing", "how to use grammar rules correctly in the writing".

(3) Content knowledge: three categories of codes ("thesis", "argument", and "conclusion") were assembled. The code "thesis" referred to the students' statement that presented with standpoint. For example, "let audience know my viewpoint at first", "emphasise my viewpoint in each paragraph". The code "argument" contained the students' knowledge about how they give evidence to support their perspective. For example, "citing accurate data to persuade" and "the readable reasons"; "contrast different arguments" and "prove my viewpoint with examples". The code "conclusion" referred to the formal and final arrangement of the writing. For example, "I will reemphasise my viewpoint at last".

(4) Rhetorical knowledge: three categories of codes ("writer-reader interactions", "purposes of arguing", "writer-content interactions") were aggregated. The code "writerreader interactions" contained the students' statements about their considerations of 
audience. For example, "let the reader know my viewpoint", and "identify readers' possible arguments and persuade them". The code "purposes of arguing" referred to the students' presentation that contained their thinking about aims in argumentation. For example, "my viewpoint", "my writing level", "Chinese education cultural", "my experience", and "the topic". The code "writer-content interactions" contained the students' statements about their considerations of writing content in argumentation. For example, "understandability of reasons", "reliability of the examples", "unify examples with my viewpoint", and "use words and grammar accurately".

(5) Process knowledge: three categories of codes ("gathering", "classifying", "evaluating") were aggregated when we summarised the participants' considerations about composing procedures in the writing. The code "gathering" contained the students' statements of classifying reasons and gathering information in themes. The code "classifying" included their answers about classifying evident reasons. The code "evaluating" encompassed a more complex composing process, including understanding, summary, gathering, and evaluating argumentative reasons.

\section{Appendix E. Writing Scoring Rubric}

\begin{tabular}{|c|c|c|c|}
\hline & Level 1 & Level 2 & Level 3 \\
\hline Content inclusion (20\%) & $\begin{array}{l}\text { Makes some arguments that } \\
\text { related to the topic. The content } \\
\text { can be tangential from the topic. } \\
(0-6)\end{array}$ & $\begin{array}{l}\text { Includes most argument elements } \\
\text { (e.g., position statement, main } \\
\text { points, evidence, restatement). } \\
\text { Includes some useless } \\
\text { information that does not } \\
\text { contribute to argument. (7-12) }\end{array}$ & $\begin{array}{l}\text { Includes all argument elements } \\
\text { (e.g., position statement, main } \\
\text { points, evidence, restatement). } \\
\text { The content relates and } \\
\text { contributes to the argument. } \\
\text { (13-20) }\end{array}$ \\
\hline Coherence $(20 \%)$ & $\begin{array}{l}\text { Only organized at sentence level. } \\
\qquad(0-6)\end{array}$ & $\begin{array}{l}\text { Attempt to structure content with } \\
\text { grouping ideas across sentences. } \\
\text { May use simile linking words } \\
\text { (e.g., and, or, because). (7-12) }\end{array}$ & $\begin{array}{c}\text { Effective ideas grouping and } \\
\text { paragraphing. Use varied linking } \\
\text { words or phrases (e.g., although, } \\
\text { by the same token, nevertheless). } \\
(13-20)\end{array}$ \\
\hline $\begin{array}{l}\text { Audience awareness and purpose } \\
\qquad(20 \%)\end{array}$ & $\begin{array}{l}\text { Writer recognizes that his/her } \\
\text { opinion is needed in evidence. } \\
\text { The writer uses language to state } \\
\text { opinions with a personal } \\
\text { perspective. }(0-6)\end{array}$ & $\begin{array}{l}\text { Language use and writing style } \\
\text { generally appropriate to audience. } \\
\text { Writer states his/her position. } \\
\text { Some attempt to influence the } \\
\text { reader is evident. (7-12) }\end{array}$ & $\begin{array}{l}\text { Language use and writing style } \\
\text { appropriate and directed to } \\
\text { audience (e.g., attempts to } \\
\text { persuade reader). } \\
\text { Clearly stated consistent position } \\
\text { is evident. (13-20) }\end{array}$ \\
\hline $\begin{array}{l}\text { Language resources for achieving } \\
\text { the purpose }(20 \%)\end{array}$ & $\begin{array}{l}\text { Topic-related vocabulary present. } \\
\text { Often speech-like in structure and } \\
\text { uses a personal voice. (e.g., } \\
\text { I reckon) }(0-6)\end{array}$ & $\begin{array}{l}\text { Uses topic appropriate vocabulary. } \\
\text { Attempts to use language to make } \\
\text { arguments seem more objective } \\
\text { (e.g., passive structures) and } \\
\text { powerful (e.g., emotive language). } \\
\text { (7-12) }\end{array}$ & $\begin{array}{l}\text { May attempt to use persuasive } \\
\text { language (e.g., emotive } \\
\text { vocabulary) to influence readers } \\
\text { or includes or refers to the reader } \\
\text { (e.g., you would). } \\
\text { Uses language to make arguments } \\
\text { seem more objective (e.g., passive } \\
\text { structures) and/or powerful (e.g., } \\
\text { certainly, must, absolutely). } \\
(13-20)\end{array}$ \\
\hline Vocabulary and grammar $(15 \%)$ & $\begin{array}{l}\text { Limited vocabulary range: } \\
\text { frequent errors of agreement, } \\
\text { tense, number, articles, pronouns, } \\
\text { prepositions and meaning } \\
\text { confused or obscured. }(0-4)\end{array}$ & $\begin{array}{l}\text { Appropriate vocabulary range: } \\
\text { several errors of agreement, tense, } \\
\text { number, articles, pronouns, } \\
\text { prepositions but meaning seldom } \\
\text { obscured. (5-9) }\end{array}$ & $\begin{array}{l}\text { Sophisticated vocabulary range: } \\
\text { few errors of agreement, tense, } \\
\text { number, articles, pronouns, } \\
\text { prepositions (10-15) }\end{array}$ \\
\hline Mechanics (5\%) & $\begin{array}{l}\text { Frequent errors of spelling, } \\
\text { punctuation, capitalization, } \\
\text { paragraphing. }(0-1)\end{array}$ & $\begin{array}{l}\text { Occasional errors of spelling, } \\
\text { punctuation, capitalization, } \\
\text { paragraphing. (2-3) }\end{array}$ & $\begin{array}{c}\text { Few errors of spelling, } \\
\text { punctuation, capitalization, } \\
\text { paragraphing. }(4-5)\end{array}$ \\
\hline
\end{tabular}

\section{References}

1. Cheng, X.L.; Zhang, L.J. Sustaining university English as a foreign language learners' writing performance through provision of comprehensive written corrective feedback. Sustainability 2021, 13, 8192. [CrossRef]

2. Hyland, K. Second Language Writing; Cambridge University Press: Cambridge, UK, 2019.

3. Zhang, L.J. Second language writing as and for second language learning. J. Second Lang. Writ. 2013, 22, 446-447. [CrossRef] 
4. Zhang, L.; Zhang, L.J. Fostering stance-taking as a sustainable goal in developing EFL students' academic writing skills: Exploring the effects of explicit instruction on academic writing skills and stance deployment. Sustainability 2021, 13, 4270. [CrossRef]

5. Zhang, L.J.; Cheng, X.L. Examining the effects of comprehensive written corrective feedback on L2 EAP students' linguistic performance: A mixed-methods study. J. Engl. Acad. Purp. 2021, 49, 101043. [CrossRef]

6. Chen, J.; Zhang, L.J.; Wang, X.; Zhang, T.T. Influences of SRSD revision instruction on English-as-a-foreign-language (EFL) students' self-efficacy for text revision: A mixed-methods study. Front. Phys. 2021, 12, 670100. [CrossRef]

7. Gu, X.L.; Xu, Z. Chinese novice writer-researchers' metadiscourse use in English research articles. Sustainability 2021, 13, 9523. [CrossRef]

8. Rahimi, M.; Zhang, L.J. Effects of an engaging process-genre approach on student experiences, engagement, and writing achievements. Read. Writ. Quart. 2021, 1-17. [CrossRef]

9. Zhang, L.J. Crossing literacy borders through writing: Transformational apprenticeship and repositioning of EAL learners. In Crossing Borders, Writing Texts, Being Evaluated: Cultural and Interdisciplinary Norms in Academic Writing; Golden, A., Kulbrandstad, L.A., Zhang, L.J., Eds.; Multilingual Matters: Bristol, UK, 2021; pp. 153-169.

10. Li, H.H.; Zhang, L.J. Effects of structured small-group student talk as collaborative prewriting discussions on Chinese university EFL students' individual writing: A quasi-experimental study. PLoS ONE 2021, 16, 0251569. [CrossRef]

11. Nadell, J.; McMeniman, L.; Langan, J. The Macmillian Writer: Rhetoric, Reader, Handbook, 2nd ed.; Macmillian: London, UK, 1994.

12. Vesterman, W. Reading and Writing Short Arguments; Mayfield: Mountain View, CA, USA, 2000.

13. Hirvela, A. Argumentation and second language writing: Are we missing the boat? J. Second Lang. Writ. 2017, 36, 69-74. [CrossRef]

14. Lancaster, Z. Expressing stance in undergraduate writing: Discipline-specific and general qualities. J. Engl. Acad. Purp. 2016, 23, 16-30. [CrossRef]

15. Stapleton, P. Ability to argue: Rooted in nature. J. Second Lang. Writ. 2017, 36, 83-84. [CrossRef]

16. Huang, Y.; Zhang, L.J. Does a process-genre approach help improve students' argumentative writing in English as a foreign language? Findings from an intervention study. Read. Writ. Q. 2020, 36, 339-364. [CrossRef]

17. Stapleton, P.; $\mathrm{Wu}, \mathrm{Y} . \mathrm{A}$. Assessing the quality of arguments in students' persuasive writing: A case study analyzing the relationship between surface structure and substance. J. Engl. Acad. Purp. 2015, 17, 12-23. [CrossRef]

18. Nussbaum, E.M.; Schraw, G. Promoting argument-counterargument. integration in students' writing. J. Exp. Educ. 2007, 76, 59-92. [CrossRef]

19. Qin, J.J.; Karabacak, E. The analysis of Toulmin elements in Chinese EFL university argumentative writing. System 2010, 38, 444-456. [CrossRef]

20. Johns, A.M. Augmenting argumentation in second language writing. J. Second Lang. Writ. 2017, 36, 79-80. [CrossRef]

21. Lee, J.J.; Deakin, L. Interactions in L1 and SL undergraduate student writing: Interactional metadiscourse in successful and less-successful argumentative essays. J. Second Lang. Writ. 2016, 33, 21-34. [CrossRef]

22. Kibler, A. Pursuing SL argumentative writing scholarship as a synergistic endeavor. J. Second Lang. Writ. 2017, 36, 75-76. [CrossRef]

23. Li, H.H.; Zhang, L.J.; Parr, J.M. Small-group student talk before individual writing in tertiary English writing classrooms in China: Nature and insights. Front. Psychol. 2020, 11, 570565. [CrossRef] [PubMed]

24. Hyland, K. Genre and Second Language Writing; University of Michigan Press: Ann Arbor, MI, USA, 2004.

25. Johns, A.M. Moving on from genre analysis: An update and tasks for the transitional student. J. Engl. Acad. Purp. 2015, 19, 113-124. [CrossRef]

26. Pessoa, S. How SFL and explicit language instruction can enhance the teaching of argumentation in the disciplines. J. Second Lang. Writ. 2017, 36, 77-78. [CrossRef]

27. Hyland, K. A genre description of the argumentative essay. RELC J. 1990, 21, 66-78. [CrossRef]

28. Hyon, S. Long-term effects of genre-based instruction: A follow-up study of an EAP reading course. Engl. Specif. Purp. 2001, 20, 417-438. [CrossRef]

29. Cheng, A. Transferring generic features and recontextualizing genre. awareness: Understanding writing performance in the ESP genre-based literacy framework. Engl. Specif. Purp. 2007, 26, 287-307. [CrossRef]

30. Negretti, R.; Kuteeva, M. Fostering metacognitive genre awareness in L2 academic reading and writing: A case study of pre-service English teachers. J. Second Lang. Writ. 2011, 20, 95-110. [CrossRef]

31. Yasuda, S. Genre-based tasks in foreign language writing: Developing writers' genre awareness, linguistic knowledge, and writing competence. J. Second Lang. Writ. 2011, 20, 111-133. [CrossRef]

32. Tardy, C. Building Genre Knowledge; Parlor Press: Wes Lafayette, IN, USA, 2009.

33. Gillespie, A.; Olinghouse, N.G.; Graham, S. Fifth-grade students' knowledge about writing process and writing genres. Elem. Sch. J. 2013, 113, 565-588. [CrossRef]

34. Yasuda, S. Exploring changes in FL writers' meaning-making choices in summary writing: A systemic functional approach. J. Second Lang. Writ. 2015, 27, 105-121. [CrossRef]

35. Wette, R. Using mind maps to reveal and develop genre knowledge in a graduate writing course. J. Second Lang. Writ. 2017, 38, 58-71. [CrossRef] 
36. Huang, J.C. Learning to write for publication in English through genre-based pedagogy: A case in Taiwan. System 2014, 45, 175-186. [CrossRef]

37. Uzun, K. Developing EAP writing skills through genre-based instruction. Int. J. Educ. Res. 2016, 7, $25-38$.

38. Uzun, K. The relationship between genre knowledge and writing performance. J. Teach. Engl. Specif. Acad. Purp. 2017, 5, 153-162.

39. Vygotsky, L.S.; Cole, M. Mind in Society: The Development of Higher Psychological Processes; Harvard University Press: Cambridge, MA, USA, 1978.

40. Lantolf, J.P.; Beckett, T.G. Sociocultural theory and second language acquisition. Lang. Teach. 2009, 42, 459-475. [CrossRef]

41. Paltridge, B. Context and the teaching of academic writing: Bringing together theory and practice. In Teaching Writing for Academic Purposes to Multilingual Students; John, B., Neomy, S., Rosemary, W., Eds.; Routledge: New York, NY, USA, 2017 ; pp. $23-37$.

42. Dos Santos, L.M. English language learning for engineering students: Application of a visual-only video teaching strategy. Glob. J. Engine. Edu. 2019, 21,37-44.

43. Hyland, K. Genre pedagogy: Language, literacy, and L2 writing instruction. J. Second Lang. Writ. 2007, 16, 148-164. [CrossRef]

44. Cheng, A. Language features as the pathways to genre: Students' attention to non-prototypical features and its implications. J. Second Lang. Writ. 2011, 20, 69-82. [CrossRef]

45. Feez, S.; Joyce, H. Text-Based Syllabus Design; National Centre for English Language Teaching and Research: Sydney, NSW, Australia, 1998.

46. Byrnes, H.; Maxim, H.H.; Norris, J.M. Realizing advanced foreign language writing development in collegiate education: Curricular design, pedagogy, assessment. Mod. Lang. J. 2010, 94, 1-235. [CrossRef]

47. Ryshina-Pankova, M. Toward mastering the discourses of reasoning: Use of grammatical metaphor at advanced levels of foreign language acquisition. Mod. Lang. J. 2010, 94, 181-197. [CrossRef]

48. Paltridge, B. Genre and English for specific purposes. In The Handbook of English for Specific Purposes; Paltridge, B., Starfield, S., Eds.; Wiley: Oxford, UK, 2014; pp. 347-360.

49. Cheng, A. More than "language focus boxes": The place of language in genre-based pedagogies. J. Second Lang. Writ. 2018, 46, 100678. [CrossRef]

50. Badger, R.; White, G. A process genre approach to teaching writing. ELT J. 2000, 54, 153-160. [CrossRef]

51. Deng, L.; Chen, Q.; Zhang, Y. Developing Chinese Efl Learners' Generic Competence: A Genre-Based E Process Genre Approach; Springer: New York, NY, USA, 2016.

52. Cheng, A. Analyzing genre exemplars in preparation for writing: The case of an L2 graduate student in the ESP genre-based instructional framework of academic literacy. Appl. Linguist. 2008, 29, 50-71. [CrossRef]

53. Devitt, A.; Reiff, M.A.; Bawarshi, A. Scenes of Writing: Strategies for Composing With Genres; Pearson/Longman: New York, NY, USA, 2004.

54. VanDerHeide, J. Classroom talk as writing instruction for learning to make writing moves in literary arguments. Read. Res. Q. 2017, 53, 323-344. [CrossRef]

55. Gill, A.A.; Janjua, F. Genre pedagogy and ells' writing skills: A theme analysis. Engl. Lang. Teach. 2020, 13, 141. [CrossRef]

56. Creswell, J.W. Research Design: Qualitative, Quantitative, and Mixed Methods Approaches, 4th ed.; Sage: Los Angeles, CA, USA, 2014.

57. Zhang, L.J. Reflections on the pedagogical imports of western practices for professionalizing ESL/EFL writing and writing-teacher education. Aust. Rev. Appl. Linguist. 2016, 39, 203-232. [CrossRef]

58. Zhang, Z. Business English students learning to write for international business: What do international business practitioners have to say about their texts? Engl. Specif. Purp. 2013, 32, 144-156. [CrossRef]

59. Flick, U. Mapping the field. In The SAGE Handbook of Qualitative Data Analysis; Flick, U., Ed.; Sage: London, UK, 2013 ; pp. 3-18.

60. Schreier, M. Qualitative content analysis. In The SAGE Handbook of Qualitative Data Analysis; Flick, U., Ed.; Sage: London, UK, 2013; pp. 170-183.

61. Toulmin, S.E. The Use of Argument; Cambridge University Press: Cambridge, UK, 2003.

62. Stapleton, P. Assessing critical thinking in the writing of Japanese university students: Insights about assumptions and content familiarity. Writ. Commun. 2001, 18, 506-548. [CrossRef]

63. Liu, F.; Stapleton, P. Counterargumentation and the cultivation of critical thinking in argumentative writing: Investigating washback from a high-stakes test. System 2014, 45, 117-128. [CrossRef]

64. Cohen, J. Statistical Power Analysis for the Behavioral Sciences, 2nd ed.; Academic Press: New York, NY, USA, 1988.

65. Glasswell, K.; Parr, J.; Aikman, M. Development of the asTTle Writing Assessment Rubrics for Scoring Extended Writing Tasks; University of Auckland: Auckland, New Zealand, 2001; Technical Report.

66. Kuteeva, M.; Negretti, R. Graduate students' genre knowledge and perceived disciplinary practices: Creating a research space across disciplines. Engl. Specif. Purp. 2016, 41, 36-49. [CrossRef]

67. Benesch, S. Genres and processes in a sociocultural context. J. Second Lang. Writ. 1995, 4, 191-195. [CrossRef]

68. Jwa, S. Genre Knowledge Development: Tracing Trajectories of L2 Writers' Transitions to Different Disciplinary Expectations in College Writing. Ph.D. Thesis, The University of Arizona, Tucson, AZ, USA, 2015.

69. Wei, X.; Zhang, L.J.; Zhang, W.X. Associations of L1-to-L2 rhetorical transfer with L2 writers' perception of L2 writing difficulty and L2 writing proficiency. J. Engl. Acad. Purp. 2020, 47, 100907. [CrossRef]

70. Negretti, R. Calibrating genre: Metacognitive judgments and rhetorical effectiveness in academic writing by L2 graduate students. Appl. Linguist. 2015, 38, 512-539. [CrossRef] 
71. Yu, X. Lexical features in argumentative writing across English writers from different language backgrounds. J. Second Lang. Stud. 2020, 3, 82-110. [CrossRef]

72. Ellis, R.; Johnson, K.E.; Henry, A.; Roseberry, R.L. An evaluation of a genre-based approach to the teaching of EAP/ESP writing. TESOL Q. 1998, 32, 147-156.

73. Kwee, C.T.T. I want to teach sustainable development in my English classroom: A case study of incorporating sustainable development goals in English teaching. Sustainability 2021, 13, 4195. [CrossRef]

74. Zhang, L.; Zhang, L.J. Development and validation of the Questionnaire on EFL Students' Perceptions of Authorial Stance in Academic Writing. Appl. Linguist. Rev. 2021, 1-24. [CrossRef]

75. Sun, Q.Y.; Zhang, L.J.; Carter, S. Investigating students' metacognitive experiences: Insights from the English as a Foreign Language Learners' Writing Metacognitive Experiences Questionnaire (EFLLWMEQ). Front. Psych. 2021, 12, 1-15. [CrossRef]

76. Teng, L.S.; Zhang, L.J. Effects of motivational regulation strategies on writing performance: A mediation model of self-regulated learning of writing in English as a second/foreign language. Meta. Learn. 2018, 13, 213-240. [CrossRef]

77. Zhang, L.J.; Thomas, N.; Qin, T.L. Language learning strategy research in System: Looking back and looking forward. System 2019, 84, 87-93. [CrossRef] 